\title{
Plasma C-peptide and Serum Insulin Antibodies in Diabetic Patients Receiving Pancreatic Transplants
}

\author{
J. Östman, P. Arner, C.-G. Groth, R. Gunnarsson, Lise Heding, and G. Lundgren \\ Department of Medicine and Division of Transplantation Surgery and Department of Surgery, Huddinge Hospital, Karolinska Institute, \\ Stockholm, Sweden, and Novo Research Laboratory, Copenhagen, Denmark
}

Summary. Plasma C-peptide and serum insulin antibody levels were determined in 5 diabetic patients undergoing vascularized pancreatic transplantation. The grafts functioned well at first and exogenous insulin could be withdrawn, but one to 7 weeks later the grafts were rejected. After the transplantation there was an increase in the fasting plasma C-peptide level, and B-cell stimulation with glucose or glucagon evoked a $\mathrm{C}$-peptide response. Healing of ischaemic damage was reflected in an increase in the C-peptide level. During graft rejection the C-peptide level fell. Measurement of plasma C-peptide levels provides a direct index of the B-cell function of the pancreatic graft. After transplantation the insulin antibody level fell exponentially, with an apparent half life of 10-11 days, whereas the level of total IgG was variable. The results indicate that formation of insulin antibodies ceases immediately on removal of the immunogenic stimulus, that is, on withdrawal of xenogeneic insulin.

Key words: C-peptide, insulin antibodies, glucose tolerance, segmental pancreatic transplantation, pancreatic transplant rejection, brittle diabetes mellitus.

The object of pancreatic transplantation in diabetes mellitus is to provide the patient with normal insulinsecreting tissue, thus restoring metabolism to normal [1]. In patients receiving pancreatic transplants it is desirable to monitor directly B-cell function as well as blood glucose levels. This would be of particular value in the differential diagnosis of various causes of hyperglycaemia, such as graft failure, high-dose corticosteroid therapy, and post-operative stress. We have therefore studied plasma C-peptide levels as a measure of graft B-cell function in patients with pan- creatic transplants. Since the provision of a pancreatic transplant offered a unique opportunity for withdrawing exogenous insulin it was also considered of interest to examine the levels of insulin-binding antibodies in these patients.

\section{Material and Methods}

\section{Patients}

The studies were carried out on 5 diabetic patients receiving vascularized segmental (body and tail) pancreatic grafts. Exocrine drainage was provided by various methods (Table 1). Clinical characteristics of the individual patients, including the indications for transplantation and the number of days that the grafts functioned, are presented in Table 1 . The immunosuppressive regimen included azathioprine $(1-3 \mathrm{mg} / \mathrm{kg} /$ day $)$, anti-lymphocyteglobulin (Behring) (30 mg/kg/day given intravenously), and steroids. Prednisone treatment commenced at a dose of $120-200 \mathrm{mg} /$ day, and was gradually reduced to $30-35 \mathrm{mg}$ /day 1 month after the transplantation. In patients $1-3,1 \mathrm{~g}$ of $\alpha$-methyl prednisolone was injected intravenously on the first 3 days after transplantation. Graft rejection was treated with $1 \mathrm{~g}$ IV doses of $\alpha$-methyl prednisolone, and $200-400 \mathrm{mg}$ of prednisone orally in patients 2 and 3 . The postoperative management and clinical course of these patients have been reported in detail elsewhere $[2,3]$.

\section{Assays}

Blood glucose concentration was determined by the hexokinase method (normal fasting range, 3.1-5.6 mmol/1). Over a 2-month period prior to the pancreatic transplantation a modified $\mathrm{M}$-index [4] was determined from all the blood glucose values obtained, usually $2-5$ per day. After transplantation the index was calculated again, but now from the 6 daily blood glucose determinations performed in the week in which the best control was observed. The Cpeptide level in the plasma of 3 patients (1,2 and 3) was determined after acid extraction, using an insulin- proinsulin antiserum (M 1181). Synthetic human C-peptide was used as the standard and ${ }^{125} \mathrm{I}$-Tyr-C-peptide as the tracer. Prior to the C-peptide determinations the proinsulin was removed by binding to insulin antibodies coupled to Sepharose. In patients 4 and 5 the antiserum $M$ 
Table 1. Clinical characteristics and course in 5 patients with diabetes mellitus undergoing segmental pancreatic transplantation

\begin{tabular}{|c|c|c|c|c|c|c|c|c|c|}
\hline \multirow[t]{2}{*}{ Patient } & \multirow{2}{*}{$\begin{array}{l}\text { Type of ductal } \\
\text { drainage }\end{array}$} & \multirow[t]{2}{*}{ Sex } & \multirow{2}{*}{$\begin{array}{l}\text { Age } \\
\text { (years) }\end{array}$} & \multirow{2}{*}{$\begin{array}{l}\text { Duration } \\
\text { of insulin } \\
\text { requiring } \\
\text { diabetes } \\
\text { (years) }\end{array}$} & \multirow{2}{*}{$\begin{array}{l}\text { Indication } \\
\text { for trans- } \\
\text { plantation }\end{array}$} & \multicolumn{2}{|l|}{ M-index ${ }^{a}$} & \multirow{2}{*}{$\begin{array}{l}\text { Duration of } \\
\text { graft function } \\
\text { and cause } \\
\text { of failure }\end{array}$} & \multirow[t]{2}{*}{ (days) } \\
\hline & & & & & & $\begin{array}{l}\text { Before } \\
\text { trans- } \\
\text { plantation }\end{array}$ & $\begin{array}{l}\text { After } \\
\text { trans- } \\
\text { plantation }\end{array}$ & & \\
\hline 1 & Duct ligation & M & 31 & 20 & Brittle diabetes & $145(267)$ & $16(23)$ & Graft rejection & 41 \\
\hline 2 & $\begin{array}{l}\text { Pancreatico- } \\
\text { jejunostomy }\end{array}$ & M & 39 & 23 & $\begin{array}{l}\text { Loss of vision } \\
\text { due to optic } \\
\text { nerve atrophy }\end{array}$ & $66(88)$ & $12(31)$ & Graft rejection & 35 \\
\hline 3 & $\begin{array}{l}\text { Pancreatico- } \\
\text { jejunostomy }\end{array}$ & $\mathrm{F}$ & 35 & 8 & $\begin{array}{l}\text { Labile diabetes } \\
\text { and sensory } \\
\text { neuropathy }\end{array}$ & $134(90)$ & $23(34)$ & $\begin{array}{l}\text { Graft rejection } \\
\text { and wound } a b- \\
\text { scess }\end{array}$ & 7 \\
\hline 4 & $\begin{array}{l}\text { Ducto- } \\
\text { jejunostomy }\end{array}$ & M & 32 & 24 & $\begin{array}{l}\text { Progressive } \\
\text { angiopathy }\end{array}$ & $47(61)$ & $5(44)$ & Graft rejection & 51 \\
\hline 5 & $\begin{array}{l}\text { Ducto- } \\
\text { jejunostomy }\end{array}$ & F & 30 & 17 & $\begin{array}{l}\text { Progressive } \\
\text { angiopathy and } \\
\text { sensory } \\
\text { neuropathy }\end{array}$ & $68(84)$ & $4(33)$ & Graft rejection $^{b}$ & 43 \\
\hline
\end{tabular}

${ }^{a}$ Calculated from all the blood glucose values (number within parentheses) 2 months before transplantation, and in the week in which the best control was observed after transplantation

b After withdrawal of immunosuppression

1230 was used in the C-peptide assay. Because of low cross-reactivity no proinsulin extraction was required. The detection limit for the assay was $0.03 \mathrm{nmol} / \mathrm{l}$ for both anti-sera. The mean level of $\mathrm{C}$ peptide in normal fasting subjects is $0.35 \pm 0.09$ (SD) nmol/1 [5]. A "C-peptide index" was calculated as the quotient:

$\frac{\text { plasma C-peptide concentration }(\mathrm{nmol} / \mathrm{l})}{\text { plasma glucose concentration }-2.5(\mathrm{mmol} / \mathrm{l})}$

The factor of -2.5 was introduced as C-peptide secretion ceases below a glucose concentration of $2.5 \mathrm{mmol} / \mathrm{l}$.

The methods for determining insulin binding to insulin antibodies (IgG) and the total concentration of $\operatorname{IgG}$ in serum have been described elsewhere [6]. In an unselected group of diabetic patients receiving the same type of insulin as in the present study the insulin antibody capacity ranged from 0.25 to $2.5 \mathrm{U} / 1$ [6]. Bcell stimulation was tested with an IV injection of glucose $(25 \mathrm{~g})$ or glucagon ( $1 \mathrm{mg}$ ). The $\mathrm{k}$-value in $\% / \mathrm{min}$ was determined according to Ikkos and Luft [7].

\section{Results}

The grafts functioned well at first and exogenous insulin was withdrawn within 24 hours. One to 6 weeks later, however, the grafts ceased to function owing to rejection (Table 1). The modified M-index (normal value $<4$ ), calculated for the best week after transplantation, was almost normal in 2 patients and improved considerably in the other 3 (Table 1 ).

\section{C-peptide}

Before transplantation the fasting/plasma C-peptide level in 1 of the patients (number 2) averaged $0.33 \mathrm{nmol} / 1$, while in the others it was low or unde- tectable (Table 2). After the transplantation the levels were well within the normal range for all patients $(0.32-2.88 \mathrm{nmol} / \mathrm{l})$. The blood glucose concentrations at the same times ranged from 2.1 to $12.1 \mathrm{mmol} / 1$.

In the one patient (number 2), in whom the Cpeptide level before transplantation was almost normal, there was no C-peptide response to an IV glucose load at that time (Fig. 1). The k-value of $0.40 \% / \mathrm{min}$ was also abnormal. On days 7 and 21 after transplantation, while the pancreatic graft was still functioning, the IV glucose load caused an increase in plasma C-peptide of about $50 \%$ and the glucose disappearance rate was within the normal range (Fig. 1).

In patient number $4 \mathrm{~B}$-cell function was assessed on the basis of glucagon stimulation. The C-peptide response was more marked on day 36 than on day 47 , when a rising postprandial glucose level indicated the onset of rejection. The blood glucose curves were similar, however (Fig. 2).

In 2 patients frequent determinations of the Cpeptide and blood glucose levels were performed over one day, both soon after transplantation and during graft rejection. On the latter occasion the $\mathrm{C}$ peptide levels were low in relation to the blood glucose concentration (Figs. 3 and 4). In patient number 4 treatment of graft rejection led to recovery of the C-peptide/glucose quotient (Fig. 4). Neither before transplantation nor after graft removal was C-peptide detectable in these 2 patients. 
Table 2. Fasting plasma C-peptide and simultaneous plasma glucose levels before pancreatic transplantation and after, when the graft was functioning well

\begin{tabular}{|c|c|c|c|c|c|c|c|c|c|c|}
\hline \multirow[b]{3}{*}{ Patient } & \multicolumn{5}{|c|}{ Before transplantation } & \multicolumn{5}{|c|}{ After transplantation } \\
\hline & \multirow[b]{2}{*}{$n$} & \multicolumn{2}{|l|}{$\begin{array}{l}\text { C-peptide } \\
\mathrm{nmol} / 1\end{array}$} & \multicolumn{2}{|c|}{$\begin{array}{l}\text { Glucose } \\
\mathrm{mmol} / 1\end{array}$} & \multirow[b]{2}{*}{$n$} & \multicolumn{2}{|c|}{$\begin{array}{l}\text { C-peptide } \\
\text { nmol/1 }\end{array}$} & \multicolumn{2}{|c|}{$\begin{array}{l}\text { Glucose } \\
\mathrm{mmol} / 1\end{array}$} \\
\hline & & Mean & Range & Mean & Range & & Mean & Range & Mean & Range \\
\hline 1 & 2 & 0.07 & $0.05-0.08$ & 16.7 & $7.9-25.4$ & 3 & 0.42 & $0.32-0.52$ & 3.1 & $2.1-3.8$ \\
\hline 2 & 4 & 0.33 & $0.27-0.40$ & 8.3 & $1.8-11.5$ & 3 & 0.93 & $0.60-1.00$ & 7.9 & $5.5-12.1$ \\
\hline 3 & 6 & undetectable & & 21.4 & $17.7-24.1$ & 4 & 1.33 & $0.93-1.95$ & 8.3 & $6.3-10.1$ \\
\hline 4 & 1 & undetectable & & 11.5 & & 9 & 1.50 & $0.65-2.88$ & 5.3 & $4.2-7.3$ \\
\hline 5 & 3 & 0.04 & $0-0.11$ & 13.2 & $8.6-17.0$ & 9 & 1.77 & $1.03-2.80$ & 7.3 & $6.5-8.5$ \\
\hline
\end{tabular}

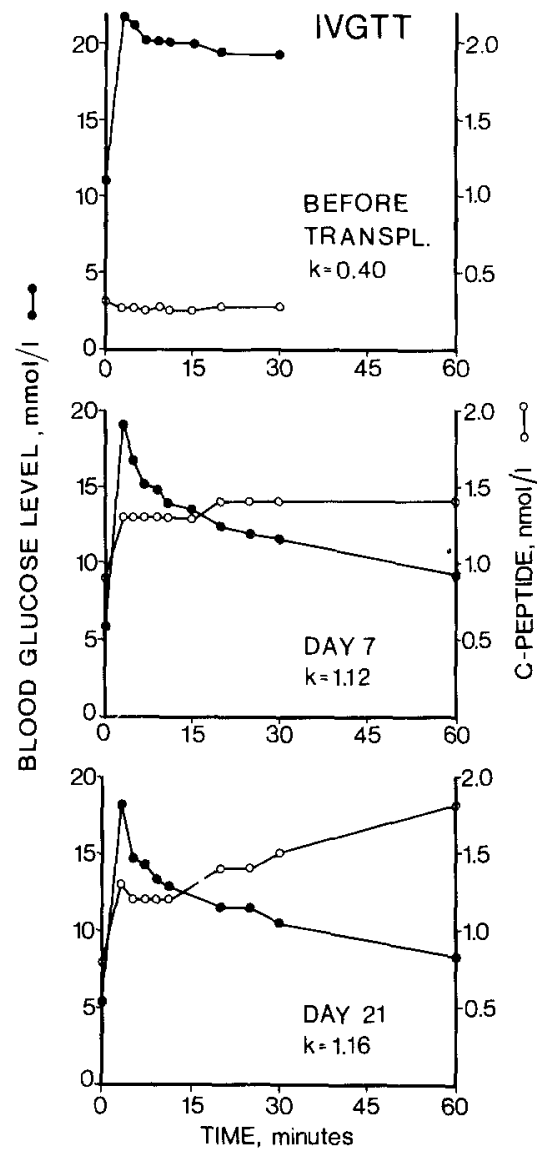

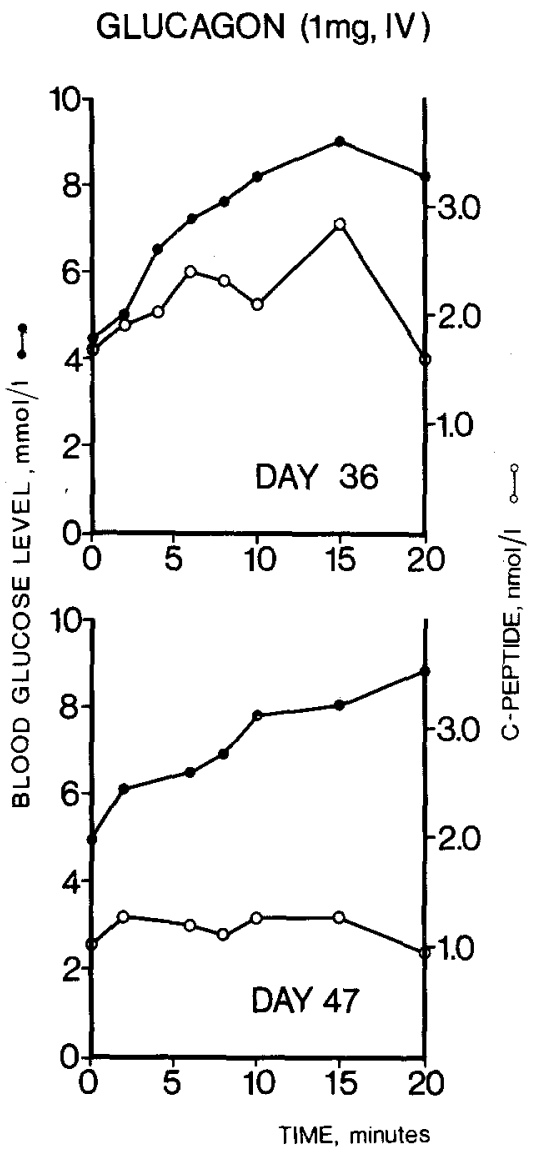

Fig. 1. Intravenous glucose tolerance test with simultaneous plasma C-peptide measurements before, and 7 and 21 days after pancreatic transplantation, when the graft was functioning well. Note the normalization of the $\mathrm{k}$-value and the marked response of the C-peptide after the transplantation. Patient 2

Fig. 2. Glucagon stimulation test with determination of blood glucose and plasma Cpeptide on day 36 after pancreatic transplantation, when the graft was functioning well, and on day 47 after onset of severe rejection. Note the disappearance of the Cpeptide response during rejection. Patient 4
A longitudinal study of the graft-B-cell function soon after transplantation was made in patient number 5. A gradual rise in the $\mathrm{C}$-peptide index indicated a progressive improvement in graft function, presumably due to healing of ischaemic damage occuring during the transplantation procedure (Fig. 5).

\section{Insulin Antibodies}

Four of the patients had been treated with monocomponent insulins (Actrapid, Semilente or Monotard, Novo) only for at least the 3 months before transplantation. During this time there had been no appreciable reduction in insulin antibody levels. In 


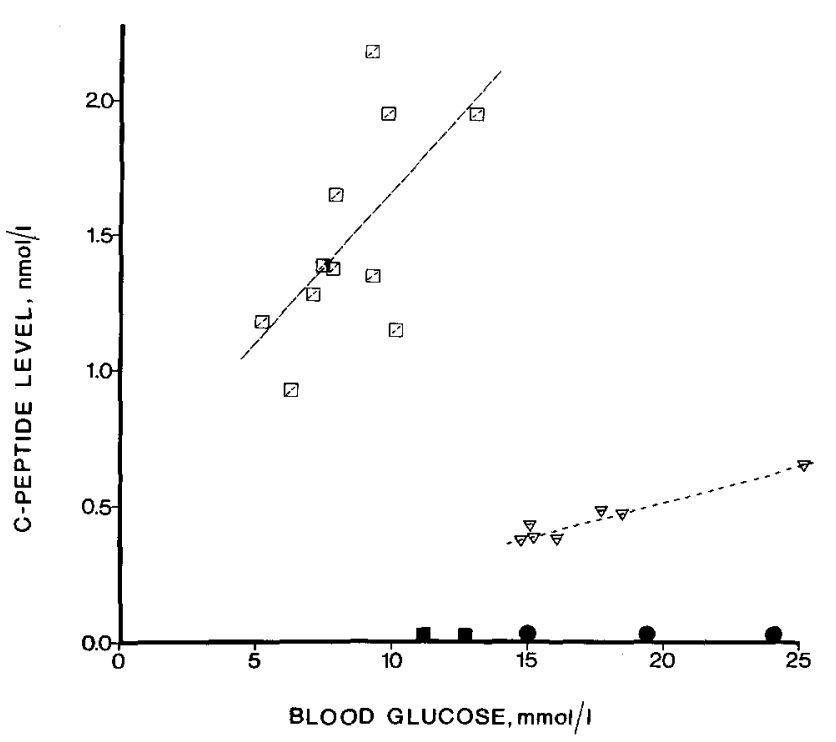

Fig. 3. Relationship between the plasma C-peptide level and the blood glucose concentration while the graft was functioning well, soon after the transplantation and during graft rejection. Rejection was accompanied by a marked shift in the ratio between the Cpeptide level and the blood glucose concentration. Patient $3 . \bullet=$ Before transplantation; $\nabla=$ Soon after transplantation; $\nabla=$ During graft rejection; $\mathbf{\square}=$ After graft removal

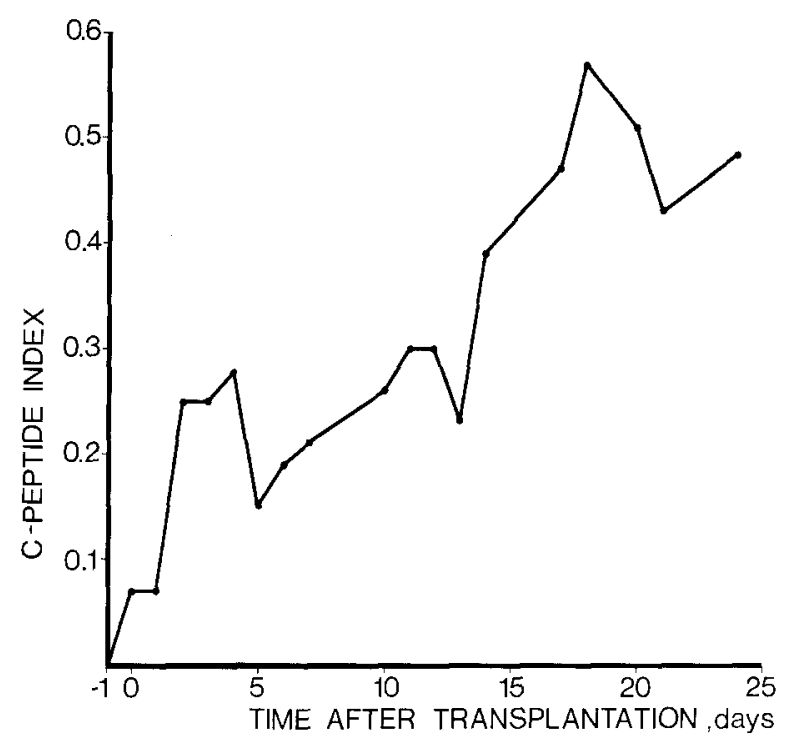

Fig. 5. The "C-peptide index" (see text) as a measure of graft function during the first 3 weeks after transplantation. During the period the graft was presumably recovering from ischaemic damage. Patient 5

one patient monocomponent insulin had been introduced shortly before the transplantation. In 2 of the 5 patients the level of insulin binding antibodies was somewhat higher than that usually found in diabetic patients [6] (Table 3).

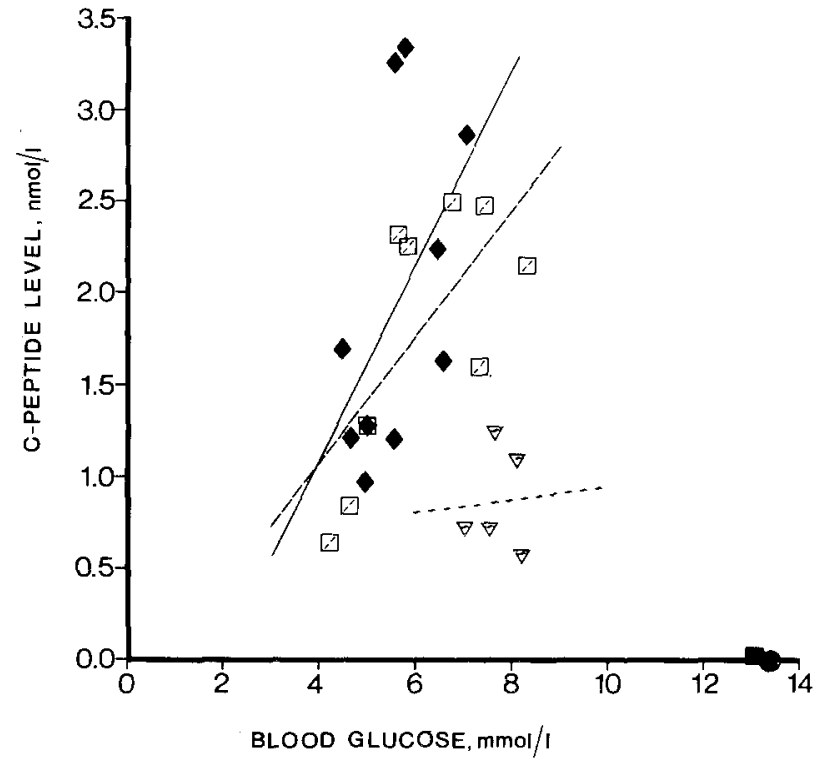

Fig. 4. Relationship between the plasma C-peptide level and the blood glucose concentration soon after the transplantation, when the graft was functioning well, during rejection, and after rejection had been reversed. Note the recovery of the C-peptide/glucose ratio with reversal of rejection. Patient $4 . \bullet=$ Before transplantation; $\nabla=$ Soon after transplantation; $\nabla=$ During graft rejection; $\downarrow=$ After treatment for rejection; $\mathbf{\square}=$ After graft removal

After transplantation there was an exponential fall in insulin antibody levels. In 4 of the 5 patients their half life was 10-11 days. In the fifth patient exogenous insulin could be withheld for only one week and the estimated half life was 14.2 days. Total IgG did not change significantly after transplantation.

\section{Discussion}

The most commonly applied criterion of endocrine function of a pancreatic graft is the blood glucose level. This may be affected, however, by a number of extraneous factors, including postoperative stress and the steroid medication required after transplantation [8]. Furthermore, it has recently been shown that a considerable part of the transplanted pancreas may be destroyed before there is a perceptible rise in the fasting blood glucose level [2].

Because most diabetic patients have a high level of insulin antibodies, which interfere with the radioimmunoassay for insulin, the serum insulin level does not provide an indicator of graft B-cell function in the immediate postoperative period. Since, however, C-peptide and insulin are secreted in equimolar amounts [9] the C-peptide level serves as an alternative index of B-cell function of the transplanted pancreas. 
Table 3. Insulin binding antibodies and total $\mathrm{IgG}$ at the time of pancreatic transplantation and when the patients had been off exogenous insulin for various times

\begin{tabular}{|c|c|c|c|c|c|c|c|}
\hline \multirow[t]{2}{*}{ Patient } & \multirow{2}{*}{$\begin{array}{l}\text { Insulin } \\
\text { requirement } \\
\text { before trans-' } \\
\text { plantation } \\
\text { U/day }\end{array}$} & \multirow{2}{*}{$\begin{array}{l}\text { Insulin } \\
\text { binding anti- } \\
\text { bodies at trans- } \\
\text { plantation } \\
\mathrm{mU} / \mathrm{ml}\end{array}$} & \multicolumn{3}{|c|}{$\begin{array}{l}\text { Disappearance rate } \\
\text { of insulin antibodies }\end{array}$} & \multicolumn{2}{|c|}{ Total IgG g/1 } \\
\hline & & & $\begin{array}{l}\text { Days of } \\
\text { obser- } \\
\text { vation }\end{array}$ & $\begin{array}{l}\text { No. of } \\
\text { obser- } \\
\text { vation }\end{array}$ & $\begin{array}{l}\text { Half } \\
\text { life, } \\
\text { days }\end{array}$ & $\begin{array}{l}\text { At trans- } \\
\text { plantation }\end{array}$ & $\begin{array}{l}\text { At the end } \\
\text { of observation }\end{array}$ \\
\hline 1 & 52 & 1.87 & 39 & 9 & 10.6 & 3.8 & 10.7 \\
\hline 2 & 48 & 3.56 & 29 & 18 & 10.6 & 7.5 & 8.1 \\
\hline 3 & 96 & 0.25 & 7 & 6 & 14.2 & 7.2 & 3.9 \\
\hline 4 & 36 & 3.81 & 51 & 10 & 10.5 & 5.7 & 8.3 \\
\hline 5 & 20 & 0.26 & 37 & 10 & 10.9 & 8.0 & 5.7 \\
\hline
\end{tabular}

Most patients with juvenile diabetes have an abnormally low C-peptide level, the concentration depending in part on the time of onset and duration of the disease [10]. In a study of 96 such patients 34 were found to have a detectable level of plasma Cpeptide, 12 of them with values within the normal range [11], although low in relation to the blood glucose level. Despite evidence of residual B-cell function in one of the transplant recipients (number 2), the absence of a C-peptide response to glucose stimulation confirms impaired B-cell function.

Pancreatic transplantation was followed by temporarily improved control of the blood glucose concentrations and an increase in the fasting C-peptide levels. Moreover, a rapid response of the C-peptide level to glucose or glucagon stimulation indicates adequate secretory function of the grafts. Where frequent assays of $\mathrm{C}$-peptide were carried out there was a definite drop in the level during rejection. At the same time there was a change in the relationship between the C-peptide and the blood glucose levels. It is thus clear that C-peptide determinations offer a valuable aid in the assessment of graft injury due to rejection. While it remains uncertain whether this method can serve as a more sensitive indicator than the blood glucose concentration, it has the advantage of being more specific. It is, however, more time consuming.

Transplantation was followed by a rapid reduction in insulin antibody levels. A similar fall was seen in the 4 patients that had been on monocomponent insulins for a long period and the 1 patient that had not. While this decline might conceivably be due to suppression of antibody synthesis by the immunosuppressive therapy, this would seem to be unlikely in view of the increase in the total amount of $\mathrm{IgG}$ observed in 3 of the patients during the postoperative course. The decline was most likely to be due to removal of the stimulating antigen, the xenogeneic insulin. The fact that the half life for disappearance was consistently 10-11 days indicates that the forma- tion of antibodies ceased immediately the stimulus was removed. A rapid reduction in the insulin antibody level has been observed in animals after immunization has been discontinued [12]. When insulin antibodies are no longer present the insulin immunoreactivity in plasma can be used to assess graft B-cell function.

It has been suggested that lability of the diabetic state is related to a low level of insulin antibodies [13, 14]. It is therefore notable that in the patient (number 1) receiving a pancreatic transplant for brittle diabetes, the insulin antibody level was high. Yue and coworkers have shown that stability of diabetes depends on residual $\mathrm{B}$-cell function but not on the concentration of insulin antibodies [15]. This is born out by our findings; when the C-peptide level rose after transplantation there was good control of blood glucose in the 2 recipients with labile diabetes. The rapid fall in the antibody level at this time apparently had no effect on the blood glucose concentration.

Acknowledgements. This investigation was supported by grants from the Swedish Medical Research Council, Swedish Diabetes Association, Nordic Insulin Fund, and O. E. and Edla Johansson's Foundation.

\section{References}

1. Lillehei RC, Simmons RL, Najarian JS, Weil R, Hisanori V, Ruiz JO, Kjellstrand CM, Goetz FC (1970) Pancreaticoduodenal allotransplantation: Experimental and clinical experience. Ann Surg 172: 405-436

2. Groth CG, Lundgren $\mathrm{G}$, Arner $\mathbf{P}$, Collste $\mathrm{H}$, Hårdstedt $\mathrm{Ch}$, Lewander R, Östman J (1976) Rejection of isolated pancreatic allografts in patients with diabetes. Surg Gynecol Obstet 143: $933-940$

3. Groth CG, Lundgren G, Gunnarsson R, Arner P, Berg B, Óstman $J$ (in press) Segmental pancreatic transplantation with duct ligation or drainage to a jejunal Roux-en-Y loop in nonuremic diabetic patients. Diabetes

4. Schlichtkrull J, Munck O, Jersild M (1965) The M-value, an index of blood sugar control in diabetics. Acta Med Scand 177: 95-102 
5. Heding LG (1975) Radioimmunological determination of human C-peptide in serum. Diabetologia 11: 541-548

6. Christiansen AaH (1973) Radioimmunoelectrophoresis in the determination of insulin binding to $\mathrm{IgG}$. Methodological studies. Horm Metab Res 5: 147-154

7. Ikkos D, Luft $R$ (1957) On the intravenous glucose tolerance test. Acta Endocrinol (Kbh) 25: 312-334

8. Gliedman ML, Tellis V, Soberman R, Rifkin H, Freed SZ, Veith FJ (1975) The clinical use of steroids in pancreatic transplantation. Transplant Proc 7: 93-98

9. Horwitz DL, Starr JI, Mako ME, Blackard WG, Rubinstein AH (1975) Proinsulin, insulin, and C-peptide concentrations in human portal and peripheral blood. J Clin Invest 55: $1278-1283$

10. Ludvigsson J, Heding LG, Larsson, Y, Leander E (1977) Cpeptide in juvenile diabetics beyond the postinitial remission period. Relation to clinical manifestations at onset of diabetes, remission and diabetic control. Acta Paediatr Scand 66: $177-184$

11. Ludvigsson J, Heding LG (1976) C-peptide in children with juvenile diabetes. A preliminary report. Diabetologia 12: $627-630$
12. Schlichtkrull J, Brande J, Christiansen AaH, Hallund O, Heding LG, Jörgensen KH (1972) Clinical aspects of insulin-antigenicity. Diabetes 21 (Suppl 2): 649-656

13. Dixon K, Exon PD, Hughes HR (1972) Insulin antibodies in aetiology of labile diabetes. Lancet I: 343-347

14. Dixon K, Exon PD, Malins JM (1975) Insulin antibodies and the control of diabetes. Q J Med 176: 543-553

15. Yue DK, Baxter RC, Turtle JR (1978) C-peptide secretion and insulin antibodies as determinants of stability in diabetes mellitus. Metabolism 27: 35-44

Received: November 9, 1979,

and in revised form: February 12, 1980

Dr. J. Östman

Department of Medicine

Huddinge Hospital

S-141 86 Huddinge

Sweden 